\title{
Advisor Yu Ying-shih Received the 2014 Tang Prize in Sinology
}

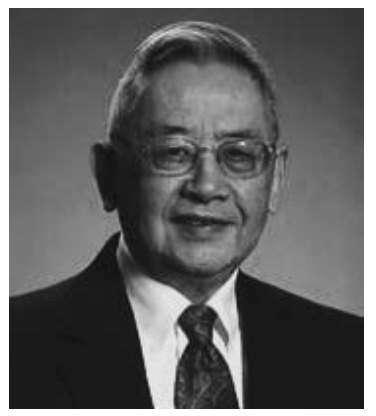

The 2014 Tang Prize in Sinology was awarded to Yu Ying-shih 余英時 for his mastery of and insight into Chinese intellectual, political, and cultural history, with an emphasis on the role of public intellectuals in the history of China. Commonly hailed as the greatest Chinese intellectual historian of his generation, Professor $\mathrm{Yu}$ is a master of Chinese political, cultural, and intellectual history who has researched and written extensively on almost every period of Chinese history. With an illustrious academic career spanning over half a century, he brought previously overlooked and forgotten aspects of Chinese culture and history to the attention of mainstream academia and society. His innovative studies in Chinese history have inspired others to discover new ways to better understand Chinese culture. Specifically, Professor Yu's original research and profound insight into the tradition of Chinese thought have revived the importance of intellectual history through his illuminating interpretation of the value and richness of Chinese culture.

In the process of exploring the history of China, Professor Yu has delved into past and present sources for Chinese history and philosophy, synthesizing them on a broad range of topics. When he published Trade and Expansion in Han China in 1967, initially publishing in English, he came to be widely recognized as a rising scholar in the United States. ${ }^{1}$ While his research was read extensively in the West, he soon realized that his work sparked little interest in the East. Hoping to reach a audience wider than the Western field of Sinology, Professor Yu decided to write and publish in Chinese. In 1976 he published in Taiwan his first collection of essays, Lishi yu sixiang (History and Thought), which later became one of his most influential works around the world, especially in the East. ${ }^{2}$ This work exemplifies his research strategy, emphasizing the interrelations among Chinese literature, history, and philosophy, as well as covering similarities and differences between Western and Eastern culture and thought and the importance of thought in the study of

1 Ying-shih Yü, Trade and Expansion in Han China: A Study in the Structure of SinoBarbarian Economic Relations (Berkeley: University of California Press, 1967).

$2 \mathrm{Yu}$ Yingshi 余英時, Lishi yu sixiang 歷史與思想 (Taipei: Lianjing Chuban Shiye Gongsi, 1976). 
history. His decision to publish in Chinese made it possible for the East to join the dialogue on Chinese historiography and diversified academic discourse in the field of Sinology, previously dominated by the West.

An indication of his vast scholarship, Professor Yu contributed to the field of Chinese literature with his Hongloumeng de liang ge shijie (The Two Worlds of Hung lou meng). ${ }^{3}$ In this work he argues that The Dream of the Red Chamber (Hongloumeng) consists of two worlds, an ideal world and the world of reality.

Seeing all of history as the history of ideas, Professor Yu has left no stone unturned in his thorough investigation of past and present changes in order to forge his own theories on the history of China, particularly the role of public intellectuals in traditional and modern China. Works in this vein include Zhongguo zhishi jieceng shilun (Historical Essays on China's Intellectual Class, 1980), Shi yu Zhongguo wenhua (Literati and Chinese Culture, 1987), Zhongguo lishi zhuanxing shiqi de zhishifenzi (Intellectuals in Transitional Periods of Chinese History, 1992), Zhongguo zhishiren zhi shi de kaocha (A Study of the History of Chinese Intellectuals, 2004), and Zhishiren yu Zhongguo wenhua de jiazhi (Intellectuals and the Value of Chinese Culture, 2007). ${ }^{4}$ His research traces the tradition of public intellectuals and the evolution of their identity and status. In a break with the past, he even includes Buddhist monks of the Northern and Southern dynasties and the Sui and Tang dynasties as public intellectuals. He brings his profound insight not only to traditional Chinese historians, but also to modern public intellectuals. In works such as Zhongguo jindai sixiangshi shang de Hu Shi (Hu Shi in the History of Modern Chinese Thought, 1984) and Qian Mu yu Zongguo wenhua (Qian Mu and Chinese Culture, 1994), he elucidated the importance of such key intellectuals as $\mathrm{Hu}$ Shi 胡適 and Qian Mu 錢穆.5 And in Chen Yinke wannian shiwen shizheng (A Critical Examination of the Later Poetry of Chen

$3 \mathrm{Yu}$ Yingshi 余英時, Hongloumeng de liang ge shijie 紅樓夢的兩個世界 (Taipei: Lianjing Chuban Shiye Gongsi, 1978).

4 Yu Yingshi 余英時, Zhongguo zhishi jieceng shilun: Gudai pian 中國知識階層史論： 古代篇 (Taipei: Lianjing Chuban Shiye Gongsi, 1980); Yu Yingshi 余英时, Shi yu Zhongguo wenhua 士与中国文化 (Shanghai: Shanghai Renmin Chubanshe, 1987); Yu Yingshi 余英時 et al., Zhongguo lishi zhuanxing shiqi de zhishifenzi 中國歷史轉型時 期的知識分子 (Taipei: Lianjing Chuban Shiye Gongsi, 1992); Yu Yingshi 余英時, Zhongguo zhishiren zhi shi de kaocha 中国知识人之史的考察, edited by Shen Zhijia 沈志佳 (Guilin: Guangxi Shifan Daxue Chubanshe, 2004); Yu Yingshi 余英時, Zhishiren yu Zhongguo wenhua de jiazhi 知識人與中國文化的價值 (Taipei: Shibao Wenhua Chuban Qiye, 2007).

5 Yu Yingshi 余英時, Zhongguo jindai sixiangshi shang de Hu Shi 中國近代思想史上的 胡適 (Taipei: Lianjing Chuban Shiye Gongsi, 1984), and Yu Yingshi 余英時, Qian Mu yu Zhongguo wenhua 錢穆與中國文化 (Shanghai: Shanghai Yuandong Chubanshe, 1994). 
Yinke, 1984), his analysis of the coded poetry that Chen Yinke 陳寅恪 penned while living under Communist rule provided readers with a glimpse into Chen's feeling of helplessness in and resistance to the political situation at the time, as well as a deeper appreciation of the sorrow and sagacity characteristic of scholars throughout Chinese history. ${ }^{6}$ Professor Yu has even provided insights into the tradition of anti-intellectualism in China in his essay "Fanzhilun yu Zhongguo zhengzhi chuantong: Lun ru, dao, fa sanjia sixiang de fenye yu huiliu" (Anti-intellectualism and the Chinese Political Tradition: Divergences and Convergences among Confucianism, Daoism, and Legalism, 1976). ${ }^{7}$ And in "Daotong yu zhengtong zhi jian: Zhongguo zhishifenzi de yuanshi xingtai" (Between the Tradition of Philosophy and the Tradition of Governance: The Original Stance of Chinese Intellectuals), he revealed the tension between the Neo-Confucian notions of the tradition of philosophy 道 統 and the tradition of governance 政統 at their origins. ${ }^{8}$

In delving into the history and development of thought, he not only mastered the intricacies of Confucian thought spanning from the classical period to the nineteenth century, but also became so well versed on such major thinkers as Fang Yizhi 方以智 (1611-1671) and Zhu Xi 朱喜 (11301200) that he has published research that has fundamentally reinterpreted these towering figures in Chinese intellectual history. ${ }^{9}$ His thousand-page masterpiece on $\mathrm{Zhu} \mathrm{Xi}$, the Confucian scholar who helped codify the Confucian canon, is more than just an enlightening study on the political culture of the Song Dynasty that reinterprets the intellectual history of the Song period and clarifies the role of public intellectuals as political actors. This two-volume work also speaks to the question of where thought, an often neglected subject, belongs in the study of history. ${ }^{10}$

In his study of Chinese history, Professor Yu saw the idea of unifying Heaven and humankind 天人合一 as the key notion driving the historical

6 Yu Yingshi 余英時, Chen Yinke wannian shiwen shizheng 陳寅恪晚年詩文釋證 (Taipei: Shibao Wenhua Chuban Shiye, 1984).

$7 \mathrm{Yu}$ Yingshi 余英時, “Fanzhilun yu Zhongguo zhengzhi chuantong: Lun ru, dao, fa sanjia sixiang de fenye yu huiliu” 反智论与中国政治传统: 论儒、道、法三家思想的分野 与汇流, in Wen shi chuantong yu wenhua chongjian 文史传统与文化重建 (Beijing: Sanlian Shudian, 2004), pp. 150-195.

8 Yu Yingshi 余英時, "Daotong yu zhengtong zhi jian: Zhongguo zhishifenzi de yuanshi xingtai” 道统与政统之间：中国知识分子的原始型态, in Zhongguo zhishiren zhi shi de kaocha 中国知识人之史的考察 (Guilin: Guangxi Shifan Daxue Chubanshe, 2004).

9 See, for instance, Yu Yingshi 余英時, Fang Yizhi wanjie kao 方以智晚節考 (A Study of the Later Years of Fang Yizhi) (Taipei: Yunchen Wenhua Shiye, 1986).

10 Yu Yingshi 余英時, Zhu Xi de lishi shijie: Songdai shidafu zhengzhi wenhua de yanjiu 朱喜的歷史世界：宋代士大夫政治文化的研究 (The Historical World of Zhu Xi: A Study of the Political Culture of Song Literati) (Taipei: Yunchen Wenhua Shiye, 2003). 
origin and development of Chinese thought. Basing this thesis on classical sources and archeological sources, he wrote Lun tianren zhi ji: Zhongguo gudai sixiang qiyuan shitan (Between Heaven and Man: An Inquiry into the Origins of Ancient Chinese Thought). ${ }^{11}$ All of these remarkable contributions have established him not only as a leading scholar, but also as a modern authority on Chinese intellectual history.

Born in Tianjin in 1930, Yu Ying-shih studied at New Asia College in Hong Kong. While there, he studied under Qian $\mathrm{Mu}$, about whom he later wrote (see note 5). In 1955 he went to Harvard on the recommendation of Qian $\mathrm{Mu}$ and received his $\mathrm{PhD}$ from that institution in 1955. After teaching at the University of Michigan, Harvard, and Yale, he came to settle in Princeton, where he retired in 2001 as Gordon Wu ' 58 Professor of Chinese Studies, Emeritus, and Professor of East Asian Studies and History, Emeritus.

Shortly before retiring, Professor Yu gave a talk in which he noted that Confucian culture throughout Chinese history has always supported limits to the mandate of Heaven, attention to the voice of the people in governing, responsible criticism of government, moral judgment based on historical comparison, and individual responsibility for social action. ${ }^{12}$ This support for democracy in China has not endeared him to the authorities in Beijing. Thus, as Professor Anthony $\mathrm{C}$. Yu of the University of Chicago once noted, "Professor Yu Ying-shih exemplifies all the qualities of the public intellectuals that he studies." In the world of scholarship, one would be hard pressed to find another Yu Ying-shih - a scholar who sees himself as a public intellectual in the traditional Chinese sense, taking on the responsibility of making the world a better place.

Copyright (C) 2014 Tang Prize Foundation, all rights reserved. http://www.tang-prize.org/ENG/Publish.aspx?CNID=300

11 Yu Yingshi 余英時, Lun tianren zhi ji: Zhongguo gudai sixiang qiyuan shitan 論天人 之際：中國古代思想起源試探 (Taipei: Lianjing Chuban Shiye, 2014).

12 Ying-shih Yü, Democracy, Human Rights, and Confucian Culture (Oxford: Asian Studies Centre, St. Antony's College, 2000). 


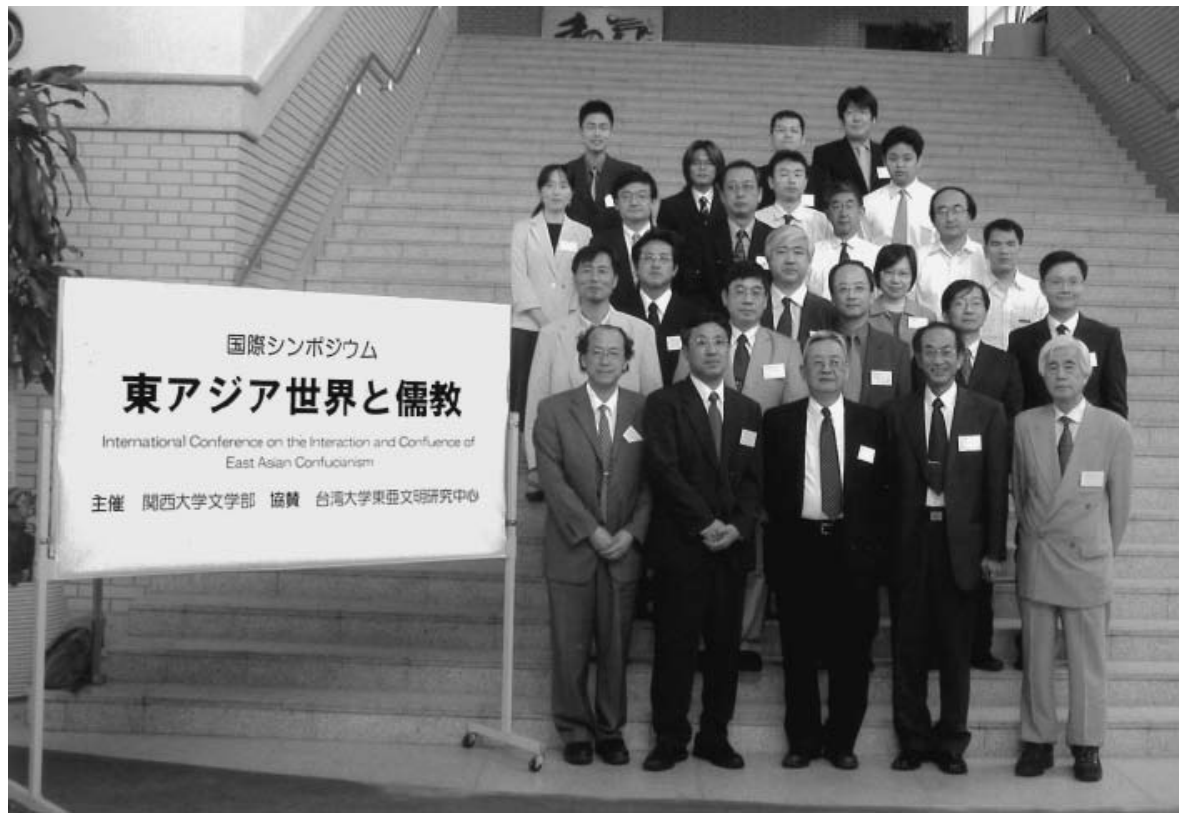

Professor Yu and Professor Koyasu Nobukuni (front row, middle and far right) gave keynotes at the 2004 conference on "The East Asian World and Confucianism" held at Kansai University

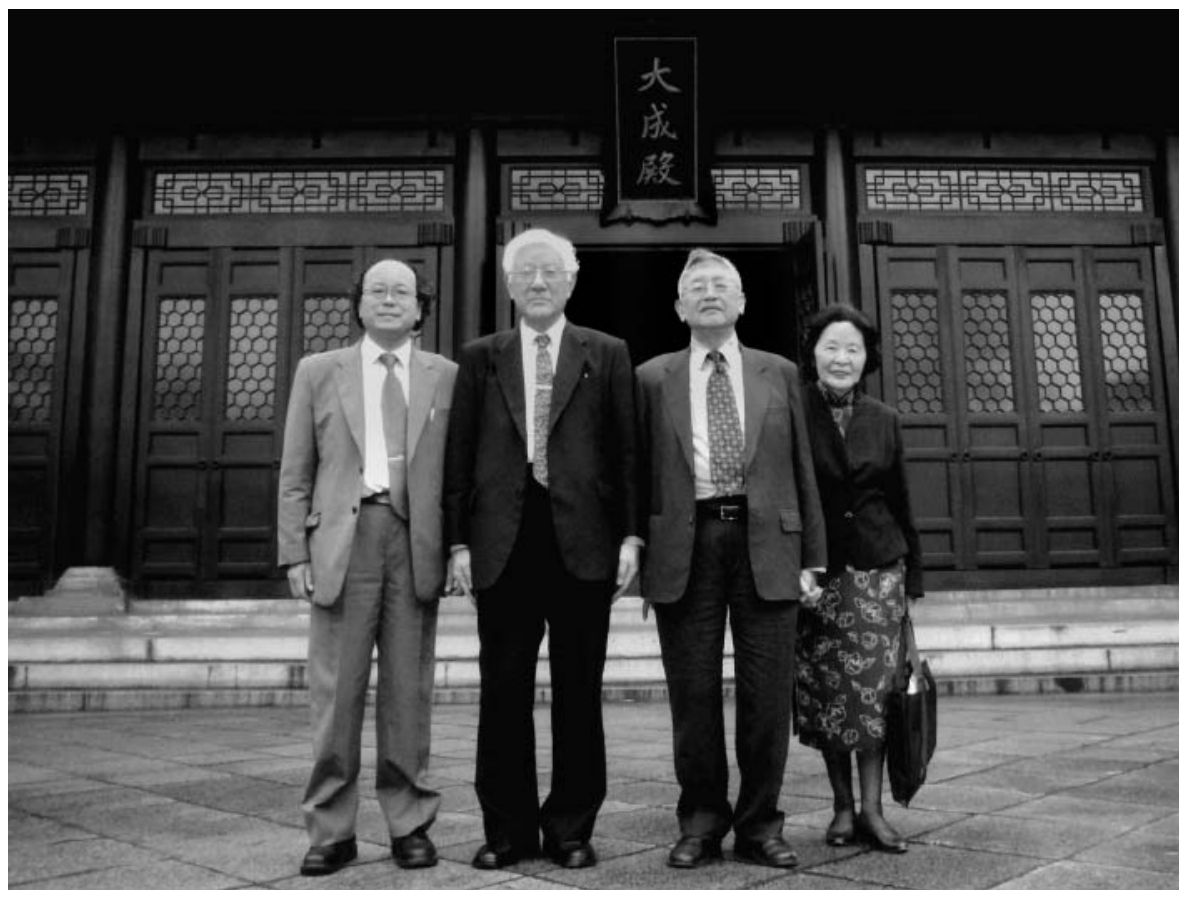

Professor Yu visited the Yushima Seidō (湯島聖堂) in Tokyo after receiving an Honorary Doctorate from Kansai University at the 2007 opening ceremony of the University's Institute for Cultural Interaction Studies, with Mrs. Yu, Professors Togawa Yoshio and De-min Tao. 